\title{
TINDAK TUTUR EKSPRESIF DALAM FILM ANIMASI UPIN DAN IPIN SIARAN TELEVISI SWASTA MNCTV (KAJIAN PRAGMATIK)
}

\author{
Elan Halid \\ Universitas Mahaputra Muhammad Yamin, Solok, Indonesia \\ elanhalid@gmail.com
}

\begin{abstract}
The problem to be discussed in this research is how the expressive speech acts in the animated film Upin and Ipin are broadcast on MNCTV private television. Pragmatics is the study of all aspects of meaning that have been covered in semantic theory, or in other words: discussing all aspects of the meaning of speech that cannot be explained completely by direct reference to the conditions of truth of the sentence spoken. Speech acts are actions that are displayed through utterances to convey one's intentions and goals to others in life situations. Expressive is a type of speech act that states something the speaker feels. Animated films are films that are the result of processing hand drawings, so that they become moving images. Animated films are basically based on fantasy stories. While the source of data in the research is the animated film Upin and Ipin. This type of research is a qualitative research with descriptive method. After the researchers conducted research and grouped the results of the research data based on expressive speech acts, the researchers obtained 27 data. The speech act of thanking found 5 data, apologizing found 4 data, congratulating found 3 data, praising found 5 data, complaining found 6 data, and blaming found 4 data. The conclusion in this study is that expressive speech acts in the form of complaining are the most commonly found in the animated film Upin and Ipin.
\end{abstract}

Keywords: Animated Film, Expressive, Pragmatics, and Speech Act.

\section{PENDAHULUAN}

Bahasa adalah salah satu ciri yang paling khas manusiawi yang membedakannya dengan makhlukmakhluk lainnya (Simanjutak, 2019:65). Bahasa sangat berperan penting dalam kegiatan interaksi sesama manusia di dalam masyarakat. Dengan bahasa, dapat berkomunikasi dengan sesama tanpa ada paksaan dari orang lain. Bahasa juga dapat digunakan sebagai alat untuk mengutarakan sesuatu kepada orang lain, mengekspresikan kepentingannya, 
ataupun mempengaruhi orang lain, sehingga orang tersebut dapat mengerti keinginan. Bahasa merupakan sebuah kunci utama dalam hal berkomunikasi yang dimiliki dan digunakan oleh manusia untuk berinteraksi dengan sesama disekitar lingkungan hidupnya. Eksistensi bahasa hampir meliputi segala bidang kehidupan karena segala sesuatu yang dihayati, dialami, dirasakan, dan dipikirkan oleh seseorang hanya dapat diketahui orang lain, jika telah diungkapkan dengan bahasa.

Kridalaksana

(2002:32)

menyatakan bahwa pragmatik memberikan kesesuaian antara konteks dengan apa yang diujarkan dalam pengungkapan bahasa (ujaran mempunyai unsur-unsur yang disebut dengan satuan informasi. Dalam ujaran satuan-satuan informasi membentuk beberapa konfigurasi, tergantung dari tujuan pengungkapan bahasa.

Penggunaan pragmatik berdasarkan pandangan bahwa untuk mengungkapkan fungsi tindak tutur dari suatu tuturan hanya dapat dilakukan dengan upaya memahami makna atau maksud tuturan tersebut (Ramadhan, 2008:37). Film animasi adalah film yang merupakan hasil dari pengelolahan gambar tangan, sehingga menjadi gambar yang bergerak. Film animasi pada dasarnya didasarkan pada ceritacerita berbau fantasi. Upin dan Ipin merupakan sepasang kakak-beradik kembar yang berusia belia yang tinggal bersama Kak Ros dan Mak Uda (biasa dipanggil Opah) di kampung Durian Runtuh setelah kematian kedua orang tua mereka sewaktu bayi.

Dalam penelitian ini terdapat bentuk tindak tutur ekspresif. Berikut ini akan diberikan salah satu contoh tindak tutur ekspresif dalam film animasi Upin dan Ipin, sebagai berikut.

Upin dan Ipin: "Terima kasih Kak"

"Suka, sayang Akak"

Kutipan kalimat di atas merupakan tuturan yang dituturkan oleh Upin dan Ipin yang berisikan tindak tutur ekspresif perasaan senang yang mengekspresikan ucapan terima kasih dan rasa sayang mereka kepada Kak Ros yang telah menjahitkan baju untuk hari raya. Upin dan Ipin mengekspresikan tindak tuturnya dengan menggunakan kata terima kasih dan sayang.

Berdasarkan latar belakang masalah di atas, maka peneliti perlu melakukan penelitian yang berjudul tindak tutur ekspresif dalam film animasi Upin dan Ipin siaran televisi swasta MNCTV kajian pragmatik. Film animasi Upin dan Ipin pertama kali tayang pada tanggal 14 September 2007 karya Sutradara dan animator yaitu Nizam bin Abd. Razak, Mohd Safwan Karim, dan Muhammad Usamah Zaid. Film animasi Upin dan Ipin ini tayang di televisi untuk mendidik anak-anak menghayati bulan Ramadhan. Peneliti melakukan penelitian dengan judul Tindak Tutur Ekpresif dalam Film Upin dan Ipin Siaran Televisi Swasta MNCTV karena peneliti ingin mengetahui langsung bagaimana tindak tutur ekspresif yang terdapat di dalam Film Upin 
dan Ipin tersebut. Tujuan penelitian ini adalah mendeskripsikan tindak tutur ekpresif di dalam Film Upin dan Ipin siaran televisi swasta MNCTV (kajian pragmatik).

\section{TINJAUAN PUSTAKA}

2.1. Hakikat Pragmatik Levinson dalam Rahardi (2009:41) mengungkapkan beberapa pengertian pragmatik yaitu: (a) pragmatik adalah kajian mengenai hubungan di antara tanda (lambang) dan penafsirannya, (b) pragmatik adalah kajian mengenai penggunaan bahasa, (c) pragmatik adalah kajian bahasa dari perspektif fungsi dalam arti bahwa kajian ini mencoba pengaruh-pengaruh dan sebabsebab nonlinguistik, (d) pragmatik adalah kajian mengenai hubunganhubungan antara bahasa dan konteks, dan (e) pragmatik adalah yang berkaitan dengan topik mengenai dengan aspek-aspek makna ujaran yang tidak dapat dijelaskan dengan mengacu langsung kepersyaratan kebenaran dan kalimat yang diujarkan. Berdasarkan beberapa paparan mengenai pragmatik di atas dapat di simpulkan bahwa pragmatik mengkaji makna tuturan yang dikehendaki oleh penutur dan menurut konteksnya.

\subsection{Tindak Tutur Ekspresif}

Tindak tutur merupakan fenomena pragmatik menyelidiki linguistik klinis yang menonjol. Tindak juga merupakan kategori yang kaya akan fenomena-fenomena pragmatik untuk dikaji oleh para ahli linguistik klinis (Cummings, 2007:363). Rahardi (2005:6) menyatakan bahwa tindak tutur itu sendiri pada dasarnya merupakan pernyataan konkret dari fungsifungsi bahasa (performance of language functions). Tindak tutur merupakan gejala individual bersifat psikologi dan keberlangsungannya ditentukan oleh kemampuan bahasa si penutur dalam menghadapi situasi tententu. Dalam peristiwa tutur lebih dilihat pada makna atau arti tindakan dalam tuturan. Hal ini sesuai dengan kegiatan betutur adalah suatu tindakan. Jika kegiatan bertutur dianggap sebagi tindakan, berarti dalam setiap kegiatan bertutur terjadi tindak tutur.

Yule (2006:93) mengemukakan bahwa tindak tutur ekspresif ialah jenis tindak tutur yang menyatakan sesuatu yang dirasakan oleh penutur. Djarot (2019:14) berpendapat bahwa tindak tutur ini berfungsi untuk mengekspresikan perasaan dan sikap mengenai keadaan hubungan. Misalnya, permintaan maaf, penyesalan dan ungkapan, serta terima kasih. Tindak tutur ekspresif berfungsi untuk mengekspresikan perasaan dan sikap. Tindak tutur ekspresif dapat dibagi menjadi 6 bentuk yaitu: (a) berterima kasih adalah ucapan yang diucapkan kepada orang yang telah menolong kita dan sesuatu hal yang sangat penting dilakukan, (b) memberi selamat adalah salah satu hal yang wajib untuk dilakukan ketika orang di sekitar kita berhasil meraih sesuatu, (c) meminta maaf adalah cara untuk menunjukkan bahwa kita mengakui berbuat salah dan telah belajar dari kesalahan itu, (d) menyalahkan adalah sesuatu yang dilakukan untuk menyalahkan 
orang lain, (e) memuji adalah adalah sesuatu pernyataan yang ditujukan kepada seseorang karena telah melakukan sesuatu hal yang baik, dan (f) mengeluh menyatakan sesuatu yang susah (penderitaan, kesakitan, kekecewaan, dan sebagainya).

\subsection{Film Animasi}

Film animasi adalah sejenis film yang berbahan mentah gambar tangan lalu diolah menjadi gambar bergerak. Pada awal penemuannya, film animasi dibuat dari berlembarberlembar kertas gambar yang kemudian 'diputar', sehingga muncul efek gambar bergerak. Dengan bantuan komputer grafis, pembuatan film animasi menjadi jauh lebih mudah dan cepat. Film animasi merupakan hasil dari gambaran tangan yang diolah menjadi bergerak bisa menggunakan teknik dua dimensi ataupun tiga dimensi. Defenisi sendiri berkembang menjadi gambar dua dimensi yang seolah-olah hidup dan dapat bergerak.

\subsection{Upin dan Ipin}

Upin dan Ipin merupakan sepasang kakak-beradik kembar yang berusia belia yang tinggal bersama Kak Ros dan Mak Uda (biasa dipanggil Opah) di kampung Durian Runtuh setelah kematian kedua orang tua mereka sewaktu bayi. Upin dan Ipin bersekolah di Tadika Mesra yang terletak dalam kawasan kampung, di mana mereka memiliki banyak teman yang bermacam-macam tingkah lakunya, seperti Mei-Mei yang imut dan berkepribadian cerdas, Jarjit Singh yang gemar membuat humor dan membuat pantun, Ehsan yang suka menyendiri, cerewet dan suka makan, Fizi (sepupu Ihsan) yang penuh keyakinan diri, tetapi suka mengejek orang lain, dan Mail yang berkemampuan untuk berjualan ayam, suka melamun, mengantuk, dan pandai berhitung.

\section{METODE PENELITIAN}

Jenis penelitian ini adalah penelitian kualitatif dengan metode deskriptif. Menurut Bogdan dan Taylor dalam Moleong (2004:4) penelitian kualitatif adalah penelitian yang menghasilkan data deskriptif berupa kata-kata tertulis dan lisan dari orang-orang dan perilaku yang dapat diamati.

Mahsun (2006:84) berpendapat bahwa penelitian bahasa secara deskriptif adalah penelitian bahasa yang dilakukan dengan mengamati fenomena suatu bahasa pada kurun waktu tertentu. Adapun data penelitian ini berupa data lunak (soft data) yang berwujud kata, kalimat ungkapan yang memiliki tindak tutur ekspresif yang terdapat dalam film animasi Upin dan Ipin, sedangkan sumber datanya berupa film animasi Upin dan Ipin. Pada penelitian ini, teknik pengumpulan data yang lazim digunakan adalah metode simak. Metode simak memiliki teknik dasar yang berwujud teknik sadap (Mahsun, 2006:90). Adapun teknik analisis data dalam penelitian ini yaitu: (a) pengumpulan data yang sudah didokumentasikan dalam bentuk video yang diunduh dari www.youtube.com dari tayangan film animasi Upin dan Ipin episode 5-6 di MNCTV,

(b) 
menyimak, mencatat, dan menganalisis bagaimana tindak tutur ekspresif yang digunakan dalam film animasi Upin dan Ipin, (c) memeriksa kembali data yang dikumpulkan, dan (d) menarik kesimpulan hasil penelitian

\section{HASIL DAN PEMBAHASAN}

\subsection{Hasil}

Dari hasil penelitian, maka data yang ditemukan di lapangan sebanyak 27 bentuk tindak tutur ekspresif. Adapun bentuk tindak tutur ekspresif tersebut yaitu: (1) mengucapkan terima kasih ditemukan 5 data, (2) meminta maaf ditemukan 4 data, (3) memberi selamat ditemukan 3 data, (4) memuji ditemukan 5 data, (5) mengeluh ditemukan 6 data, dan (6) menyalahkan ditemukan 4 data.

\subsection{Pembahasan}

Pada bab pembahasan ini peneliti akan menjabarkan tentang bentuk tindak tutur ekpsresif terdiri dari ucapan terima kasih, meminta maaf, memberi selamat, memuji, mengeluh, dan menyalahkan dalam film animasi Upin dan Ipin episode 56.

\section{Tindak Tutur Ekspresif dengan Bentuk Mengucapkan Terima kasih}

Mengucap berasal dari kata ucapan, yang berarti kata atau bagian kalimat yang dilisankan. Berterima kasih adalah ucapan yang diucapkan kepada orang yang telah menolong kita dan sesuatu hal yang sangat penting dilakukankan. Mengucapkan terimakasih berarti mengucapkan rasa syukur atau membalas budi setelah menerima kebaikan. Hal ini dapat dilihat pada data-data di bawah ini.

Data (1) Mei-Mei: Makasih

Oppah

(Terimakasih Nenek)

Data (2) Ihsan: Makasih Oppah

Pada data (1) dan (2) Mei-Mei dan Ihsan mengucapkan terimakasih kepada Oppah karena telah memberikan amplop yang berisi uang pada hari lebaran.

\section{Data (3) Upin: Makasi}

Pada data (3) Upin mengucapkan terima kasih kepada orang yang mengantar paket ke rumahnya. Surat tersebut ditujukan untuk kak Ros yang dikirim oleh teman kak Ros dari Cina.

Data (4) Upin dan Ipin: Trimakasi Oppah

Dari tuturan Upin dan Ipin pada data (4) mengucapkan terima kasih kepada Oppah, karena Oppah telah memberi uang kepada mereka berdua untuk membeli ayam goreng kesukaan mereka.

Data (5) Oppah: Terima kasih Susanti

Dari tuturan Oppah pada data (5) Oppah mengucapkan terima kasih kepada Susanti, karena Susanti dan ibunya telah membawakan Oppa kue lebaran.

2. Tindak Tutur Ekspresif dengan Bentuk Meminta Maaf

Meminta berasal dari kata yang berarti berkata-kata supaya diberi atau mendapat sesuatu, memohon, membawa, dan menimbulkan. Maaf adalah pembebasan seseorang dari kesalahan. Meminta maaf adalah cara untuk menunjukkan bahwa kita 
mengakui berbuat salah dan telah belajar dari kesalahan itu. Minta maaf berarti mengharapkan agar diberi maaf (dimaafkan) atau ungkapan permintaan ampun, dan penyesalan. Berikut ini merupakan tindak tutur ekspresif berupa meminta maaf yang terdapat dalam film animasi Upin dan Ipin siaran televisi swasta MNCTV.

Data (6) Upin: Sory sory sory

(Maaf maaf maaf)

Tuturan dari Upin pada data (6) di atas merupakan tindak tutur ekspresif berupa meminta maaf. Upin meminta maaf sambil berlari mengejar ayam dan menabrak Atuk Dalang, Paman, dan bang Shaleh, sehingga membuat mereka jatuh dan terluka, akibatnya mereka marah kepada Upin dan Ipin.

Data (7) Upin:

Assalammualaikum. Kami nak mintak maaf.

Pada data (8) Upin mau meminta maaf kepada Atuk karena telah berlari dan menyenggol Atuk sampai Atuk masuk ke dalam kuali besar yang panas.

Data (8) Upin dan teman-teman:

Atuk Oooo Atuk, kami nak minta maaf.

Pada data (8) mereka ingin minta maaf kepada Atuk Dalang karena telah mengejar ayamnya dan membuat Atuk Dalang marah.

Data (9) Upin: Minta maaf Oppah.

Pada data (9) Upin meminta maaf kepada Oppah pada hari lebaran. Pada saat lebaran dianjurkan untuk saling minta maaf dan maaf-memaafkan.

3. Tindak Tutur Ekspresif dengan Bentuk Memberi Selamat
Selamat berarti terbebas dari bahaya, malapetaka, dan bencana. Memberi selamat adalah salah satu hal yang wajib untuk dilakukan ketika orang disekitar kita berhasil meraih sesuatu. Memberi selamat juga merupakan perbuatan yang baik di mana orang yang kita beri selamat akan merasa di hargai. Hal ini dapat dilihat pada data berikut.

Data (10) Ihsan dan Fizi: Selamat hari raye.

Data (11) Upin dan Ipin: Selamat hari raye Oppah

Data (12) Susanti: Selamat hari lebaran Oppah

Pada data 10, 11, dan 12 merupakan tindak tutur ekspresif berupa memberi selamat. Ihsan, Fizi, Upin, dan Susanti memberi ucapan selamat kepada Oppah pada saat mereka pergi lebaran ke rumah Upin dan Ipin. Memberi selamat merupakan sesuatu yang sering diucapkan oleh orang-orang pada saat lebaran.

4. Tindak Tutur Ekspresif dengan Bentuk Memuji

Memuji berasal dari kata Puji yang berarti (pernyataan) rasa pengakuan dan penghargaan yang tulus akan kebaikan (keunggulan) sesuatu. Memuji berarti melahirkan kekaguman dan penghargaan kepada sesuatu yang dianggap baik, indah, gagah berani, dan sebagainya. Memuji juga dapat memuliakan nama Tuhan dan sebagainya. Memuji adalah adalah sesuatu pernyataan yang ditujukan kepada seseorang karena telah melakukan sesuatu hal yang baik. Berikut ini merupakan bentuk tindak tutur ekpresif dari memuji. 
Data (13) Mei-Mei: Oppah tampak cantik hari ne.

Dari tuturan Mei-Mei pada data (13) di atas merupakan tindak tutur ekspresif berupa memuji. Mei-Mei memuji Oppah karena Mei-Mei melihat Oppah sangat cantik saat hari lebaran.

Data (14) Upin: Oppah cantikcantik ne nak pegi kemana?

Pada data (14) terdapat bentuk tindak tutur ekspresif memuji Oppah karena kelihatan cantik sekali saat memakai kerudung dan warna baju yang senada dengan rok.

Data (15): Oppah: Bagus cucucucu Oppah

Dari tuturan Oppah pada data (15) memuji Upin dan Ipin karena mereka telah menolong anak kecil yang kelaparan dengan memberi anak kecil itu kue yang akan diberikan kepada Atuk Dalang. Oppah memuji Upin dan Ipin karena mau menolong orang yang membutuhkan.

Data (16) Upin dan Ipin: Wah, cantiknyee.

Dari tuturan Upin dan Ipin pada data (16) memuji kak Ros yang terlihat sangat cantik sekali memakai baju warna pink dan mengenakan rok panjang pada saat hari lebaran.

Data (17) Upin: Oppah cantiklah, comel.

Dari tuturan Upin pada data (17) memuji Oppah karena sangat cantik dan manis dengan memakai baju yang serasi dengan jilbab.

5. Tindak Tutur Ekspresif dengan Bentuk Mengeluh

Keluh merupakan ungkapan yang keluar karena perasaan susah (karena menderita sesuatu yang berat, kesakitan, dan sebagainya).
Mengeluh melahirkan perasaan susah dengan mengaduh, menarik napas, dan sebagainya. Mengeluh menyatakan sesuatu yang susah (penderitaan, kesakitan, kekecewaan, dan sebagainya). Tindak tutur ekspresif dengan bentuk mengeluh dapat dilihat pada data di bawah ini.

Data (18) Upin: Ha, tak boleh makan? Matilah.

Dari tuturan Upin pada data (18) di atas merupakan tindak tutur ekspresif berupa mengeluh. Upin mengeluh kepada Oppah sebab mereka diminta untuk berpuasa. Mereka mengeluh karena tidak dapat makan dan minum, serta di dalam pikiran mereka kalau berpuasa pasti bisa meninggal.

Data (19) Ipin: Tapi Oppah, kita kan kecik lagi?

Tuturan Ipin pada data (19) mengeluh karena Upin dan Ipin merasa masih kecil dan tidak perlu untuk berpuasa. Oppah menasehati Upin dan Ipin kalau berpuasa itu dimulai sejak kecil.

Data (20) Upin: Hmm... abis tu kak, apa yang ingin dilakukan lagi? dah lapar ne.

Dari tuturan Upin pada data (20) terdapat bentuk tindak tutur mengeluh karena lama sekali bisa makan dan tidak tahu lagi apa yang ingin mereka kerjakan, sebab mereka sudah sangat merasakan lapar. Kak Ros mengalihkan pikiran mereka dengan memberikan buku cerita baru.

Data (21) Upin: Alah, kapan bisa makan ne? Laparnya.

Pada data (21) Upin mengeluh karena menunggu waktu makan terlalu lama dan sudah menunjukkan 
sore hari, tetapi mereka belum juga bisa makan. Sedangkan mereka sudah sangat lapar sekali. Oppah menyuruh mereka untuk mandi.

Data (22) Upin dan Ipin:

Alaaahhhhhh

Dari tuturan Upin dan Ipin pada data (22) mereka mengeluh karena tidak dapat mencari tahu siapa anak kecil yang mengambil makanan dan minuman yang di Masjid. Pada saat itu kak Ros menyuruh mereka membuat kue secara bersama-sama.

Data (23) Upin dan Ipin:

Alaaahhh, tak ade ayam goreng.

Dari tuturan Upin dan Ipin pada data (23) mereka mengeluh tidak dapat ayam goreng dari kak Ros, karena telah menjatuhkan Atuk Dalang yang sedang memasang lampu kelip-kelip di rumah mereka.

\section{Tindak Tutur Ekspresif dengan Bentuk Menyalahkan}

Salah merupakan tidak benar, tidak betul, keliru, khilaf, menyimpang dari yang seharusnya, luput, tidak mengenai sasaran, gagal, cacat, dan kekeliruan. Menyalahkan berarti menyatakan (memandang, menganggap) salah, melemparkan kesalahan, mempersalahkan, dan menyesali. Menyalahkan adalah sesuatu yang dilakukan untuk menyalahkan orang lain. Pernyataan ini dilakukan penutur atau mitra tutur tidak benar, menyimpang dari yang seharusnya. Tindak tutur ekspresif dengan bentuk menyalahkan dapat dilihat pada data di bawah ini.

Data (24) Mei-Mei: Tu lah Raju, sebab kamulah kita kalah.

Dari tuturan Mei-Mei pada data (24) di atas merupakan tindak tutur ekspresif berupa menyalahkan. MeiMei menyalahkan Raju, disebabkan Raju yang berlari pelan, mereka kalah dengan Upin dan Ipin saat bermain.

Data (25) Raju: Mana ade, karena kamulah berat sangat.

Dari tuturan Raju pada data (25) Raju juga menyalahkan Mei-Mei karena badannya terlalu berat, sehingga mereka kalah saat bermain dengan Upin dan Ipin. Raju tidak mau disalahkan oleh Mei-Mei karena mereka kalah.

Data (26) Upin dan Ipin: Kak

Rosssssss (nada menyalahkan).

Dari tuturan Upin dan Ipin pada data (26) mereka menyalahkan kak Ros karena melakukan suatu kesalahan besar yang membuat Atuk masuk ke dalam kuali panas, mengotorkan rumah bang Saleh, membuat paman jatuh dari tangga dan kena sentrum, serta membuat Atuk Dalang marah kepada mereka karena telah mengejar ayamnya.

Data (27) Upin: Alah, ape lah bang Saleh ne, tak penat-penat balik kampung.

Dari tuturan Upin dari data (27) Upin menyalahkan bang Saleh karena pergi pulang kampung dan tidak jadi menjahitkan baju Oppah, kak Ros, Upin, dan Ipin.

\section{SIMPULAN}

Berdasarkan hasil penelitian, maka dapat ditarik kesimpulan sesuai dengan masalah yang diangkat yaitu tindak tutur ekspresif dalam film animasi Upin dan Ipin siaran televisi Swasta MNCTV (kajian pragmatik) terdapat tindak tutur ekspresif dengan bentuk ucapan 
terima kasih sebanyak 5 data, meminta maaf sebanyak 4 data, memberi selamat sebanyak 3 data, memuji sebanyak 5 data, mengeluh sebanyak 6 data, dan menyalahkan sebanyak 4 data. Tindak tutur ekspresif adalah bentuk petuturan yang berfungsi untuk menyatakan atau menunjukkan sikap psikologis penutur terhadap suatu keadaan, tindak tutur yang dilakukan, penuturnya bermaksud agar pendengar melakukan tindakan yang disebut dalam ujaran itu.

\section{REFERENSI}

Cummings, L. (2007). Pragmatik sebuah Perspektif Multidisipliner. Yogyakarta: Pustaka Belajar.

Djarot, M. 2019. Wujud Kesantunan dan Makna Dasar Pragmatik Imperatif dalam Tuturan antar Mahasiswa Melayu Sambas di Fakultas Tarbiyah dan IImu Keguruan IAIN Pontianak. Jurnal Philosophica. (II)1: 8-23.

Kridalaksana, H. (2002). Struktur, Kategori, dan Fungsi dalam Sintaksis. Jakarta: UNIKA.

Mahsun. (2006). Metode Penelitian Bahasa: Tahapan Strategi, Metode, dan Tekniknya. Jakarta: PT. Raja Grafindo Persada.

Moleong, L. J. (2004). Metodologi Penelitian Kualitatif. Bandung: Remaja Rosdakarya.

Rahardi, K. (2005). Pragmatik Kesantunan Imperatif Bahasa Indonesia. Jakarta: Erlangga.

Rahardi, K. (2009). Sosiopragmatik. Jakarta: Erlangga.
Ramadhan, S. (2008). Pragmatik Kesantunan Berbahasa: Menyibak Fenomena Berbahasa Indonesia Guru dan Siswa. Padang: UNP Press.

Simanjutak, T. A. (2019). Kesantunan Berbahasa dalam Diskusi Mahasiswa dan Relevansinya Terhadap Pembelajaran Profesi Kependidikan di FKIP UHN Pematangsiantar. Jurnal IdeBahasa. 1(1): 65-76. Link: https://jurnal.idebahasa.or.id /index.php/Idebahasa/article /view/9

Yule, G. (2006). Pragmatik. Yogyakarta: Pustaka Belajar. 
Vol. 3 No. 2

December 2021

e- ISSN 2685 - 0559
p- ISSN 2684 - 673X

Jusmal

Ide Bahasa

Inspirasi Dosen Bahasa dan Sastra 